\title{
Interpolation study on ambient gamma levels in parts of Khasi Hills, Meghalaya (India): Preliminary findings for U exploration
}

\author{
B M Kukreti ${ }^{1, *}$, G K Sharma ${ }^{2}$, Pramod Kumar ${ }^{3}$ and Sandeep Hamilton ${ }^{4}$ \\ ${ }^{1}$ Bhabha Atomic Research Centre, Trombay, Mumbai 400 085, India. \\ ${ }^{2}$ Atomic Minerals Directorate for Exploration and Research, West Block -7, R.K. Puram, \\ New Delhi 110 066, India. \\ ${ }^{3}$ Atomic Minerals Directorate for Exploration and Research, AMD Complex, Tata Nagar, \\ Jharkhand 831 002, India. \\ ${ }^{4} A M D$ Complex Nongmynsong, Shillong, Meghalaya, India. \\ *Corresponding author.e-mail: bharatkuk@gmail.com
}

This paper discusses an experimental approach to examine uranium exploration avenue over the geologically extended parts of Mahadek basin in Meghalaya, amid some of the environmental constraints. Study comprises periodic measurements of prevailing ambient gamma levels across 320 georeference points, in relation to the major litho units of Mahadek basin, covering 673 line $\mathrm{km}$ of Khasi Hills. Acquired sample data points were then analysed in geostatistical software (Surfer ${ }^{\mathrm{TM}}$ ) to develop analytical model of sample variogram having bearing on the uranium exploration in the area. Study findings have given encouraging surface indicators with mostly elevated gamma levels over the parts of West Khasi Hills. Delineated gamma anomalous zones are lithologically well correlated including to that of existing uranium occurrences in the basin. Identified anomalous zones over the parts of West Khasi Hills by this study work, are mainly associated with the Mahadek sandstone (Upper and Lower Mahadek) and Precambrian basement granites. Lower Mahadek sandstone is host rock for uranium mineralisation in the basin. Initial findings suggest with the closer spatial resolution $(\sim 1 \mathrm{~km})$ of sample data points, the approach adopted by the study work holds promising application in locating potential uranium exploration targets especially to the extended and inaccessible parts of the basin.

\section{Introduction}

Mahadek basin of Meghalaya nearly extends over a stretch of $180 \mathrm{~km}$ from the Jaintia Hills in the east to the Garo Hills in the west. In the basin, systematic exploration of Upper Cretaceous Mahadek sediments have established country's two largest sandstone-type uranium deposits, viz., Domiasiat (Kaul and Varma 1990; Sunil Kumar et al. 1990) and Wahkyn (Sen et al. 2002) in the West Khasi
Hills district. Geological evidences (Srivastava et al. 2008) in the basin indicates large uranium reserves potential of medium to small ore pocket size (grade $\left.<0.10 \% \quad \mathrm{U}_{3} \mathrm{O}_{8}\right)$ disposed at shallow depth. The favourability criteria of uranium occurrences to the extended areas in the basin have readily brought to light new locales of uranium mineralization namely Wahkyn, Lostoin, Wahkut and Umthougnkut, etc. Together with the main deposit at Domiasiat and satellite deposits, the basin as on date, host one of

Keywords. Uranium; interpolation; kriging; Mahadek sandstone; lithology; primordial radio-nuclide. 
the largest and richest grade sandstone-type uranium deposits in the country with 20,000 (plus) tonnes of proven ore reserve.

However, led by the prevailing environmental conditions, four decades of constant exploration activities in the basin could only explore about one third aerial extent of the basin area. In view of extended geological favourability also to the remaining part of the basin, there exist high uranium potential to the unexplored part of the basin. This unexplored part of the basin remains highly inaccessible due to number of factors such as thick Tertiary cover, typical prevailing tropical to subtropical climate (heavy rain falls), terrain difficulty, thick forest and poor logistics (roads and communication). Under these practical constraints, operational task often becomes most challenging and resource intensive. Apart from the proven uranium resources in the basin, significant amount of work has been undertaken in the basin to better understand the geological aspect of uranium hosting environment (Hamilton et al. 2009, 2010, 2012), abrupt discontinuity between the surface and subsurface uranium mineralization (Kukreti et al. 2012) as well status of uranium migration across the exploratory block (Kukreti and Pramod Kumar 2013; Kukreti et al. 2015).

It is well established that the surrounding rock/ soils medium exhibits considerable variation in ambient gamma levels (IAEA 1990) owing to different chemical and mineralogical composition of constituting rocks that contain varying concentrations of ${ }^{40} \mathrm{~K},{ }^{238} \mathrm{U}$ and ${ }^{232} \mathrm{Th}$ primordial radio elements. Using ambient gamma level-based radiometric survey, one gets rapid and effective tool in assessing the potential uranium exploration targets and to guide the exploration activities. Amid environmental constraints observed during the field exploration operations over the major parts of Mahadek basin, an experimental (georeference based) measurement and analysis of ambient gamma levels in parts of Khasi Hills (with known uranium occurrences) is being taken up to understand spatial continuity of sample data points. With due consideration of regional geological factors, suitable interpolation of acquired sample data points (Davis 2002) now offers quick preliminary assessment (based on gamma levels) for uranium prospecting over the large and inaccessible areas in the basin.

Literature survey shows kriging based interpolation techniques as the most effective technique in several field applications including mineral exploration (Matthew Kay and Roussos Dimitrakopoulos 2000) as well as critical environmental studies (Wright et al. 2002; Abraham and Comrie 2004). Kriging offers several advantages in terms of making use of irregular-spaced sample data points, which is often the case during data acquisition phase in the field. It provides the most predictable results over the large grid area together with good overview and easier to detect pattern.

\section{Geological set-up and study area}

Meghalaya plateau considered to be the northeastern extension of the Precambrian peninsular shield comprises rocks from the oldest Precambrian gneissic complex to the recent alluvium formations (GSI 1974; Nandi 1980). The Precambrian gneissic complex (para/ortho gneisses and migmatites) and Shillong Group of rocks (mainly quartzites) are exposed in the central, eastern and northern parts of Meghalaya plateau (Acharya 1976). They are intruded by basic and ultrabasic intrusives and Neo-Proterozoic granite plutons, such as South Khasi batholith, Mylliem granite, Kyrdem granite, and Nongpoh granite (Ghosh et al. 1991). The Lower Gondwana rocks (pebble bed, sandstone and carbonaceous shale) are observed in West Garo Hills. The Sylhet trap (mainly basalt, rhyolites and acid tuffs) of Middle Jurassic age is exposed in a narrow E-W strip along the southern border of Khasi Hills (Baksi et al. 1987). The Cretaceous Mahadek sandstones and Tertiary sediments occupy southern part of the plateau and forms part of the Mahadek basin. Figure 1 shows detailed geological map of the study area under Mahadek basin.

Mahadek basin essentially stretch nearly $180 \mathrm{~km}$ length from the Jaintia Hills in the east to the Garo Hills in the west with $7-18 \mathrm{~km}$ width from south to north in Jaintia, East Khasi, West Khasi and Garo Hills districts. Fluvial Lower Mahadek arkosic sandstone (thickness $30-70 \mathrm{~m}$ ) and marine Upper Mahadek purple sandstone (thickness 50$300 \mathrm{~m}$ ) are exposed over an area of $500 \mathrm{~km}^{2}$. The remaining $1300 \mathrm{~km}^{2}$ of basin is overlain by younger Tertiary sediments (Langpar formation calcareous sandstone/shale, Shella formation alternations of sandstone and limestone, Baghmara formation - feldspathic sandstone, conglomerate and clay, etc.). The basin contains proven sandstone type uranium deposits (Kaul and Varma 1990; Sunil Kumar et al. 1990; Sen et al. 2002) in the West Khasi Hills district with uranium mineralization associated with the Lower Mahadek sandstone.

\section{Materials and methods}

\subsection{Field measurements}

Considering environmental and logistic constraints in major parts of Khasi Hills in Mahadek basin, onsite measurements of ambient gamma levels 


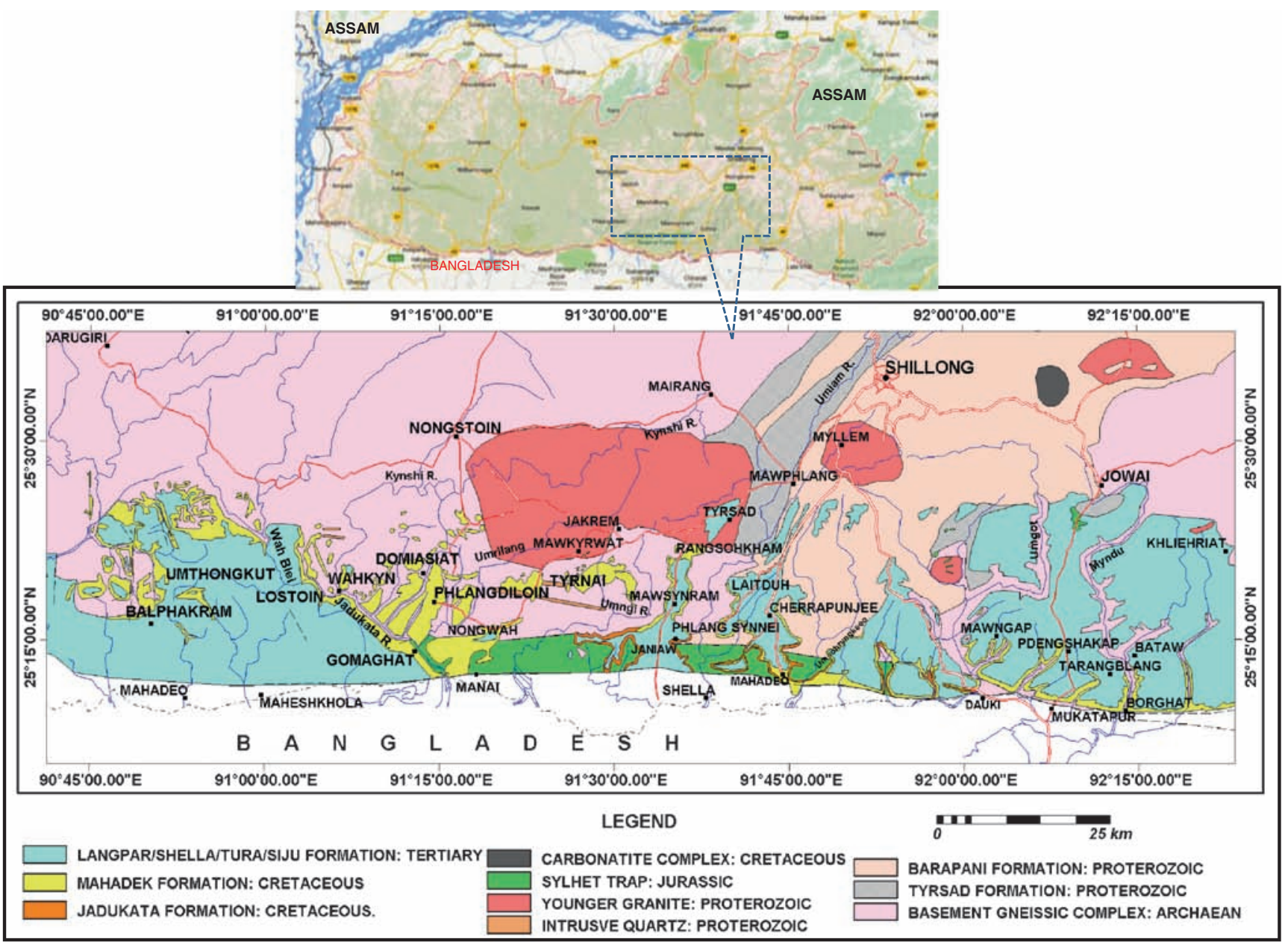

Figure 1. Parts of Khasi Hills study area (shown by dotted block) together with detailed geological map of Mahadek basin, Meghalaya (India).

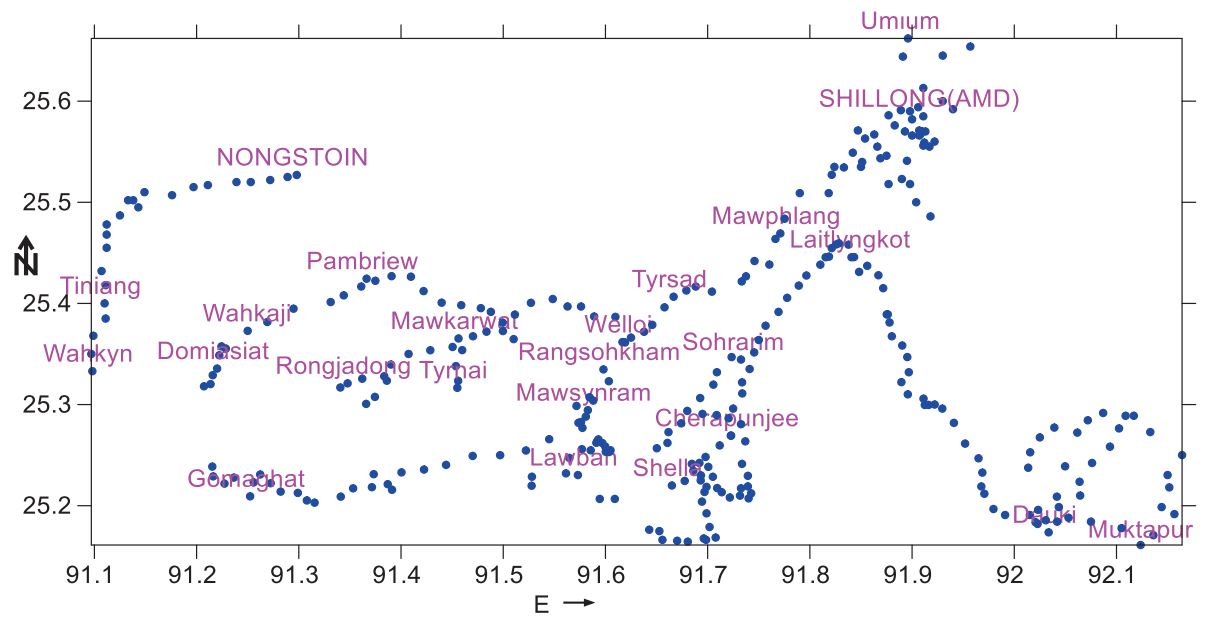

Figure 2. Georeference based field measurements over the study area (shown by blue dots) of ambient gamma levels in parts of Khasi Hills, Meghalaya (India).

were done in several phases covering 18 sectors with cumulative distance of 673 line $\mathrm{km}$ (figure 2). Pre-calibrated battery operated high sensitivity environmental radiation monitor type ER-705M (Nucleonix 2001) and GPS device (GARMIN make, model GPS-V) were used for in-situ gamma field and site coordinate measurements. During field work, georeference points were recorded at about $2-3$ line $\mathrm{km}$ periodic intervals using vehicleborne milometer such that covering major land 


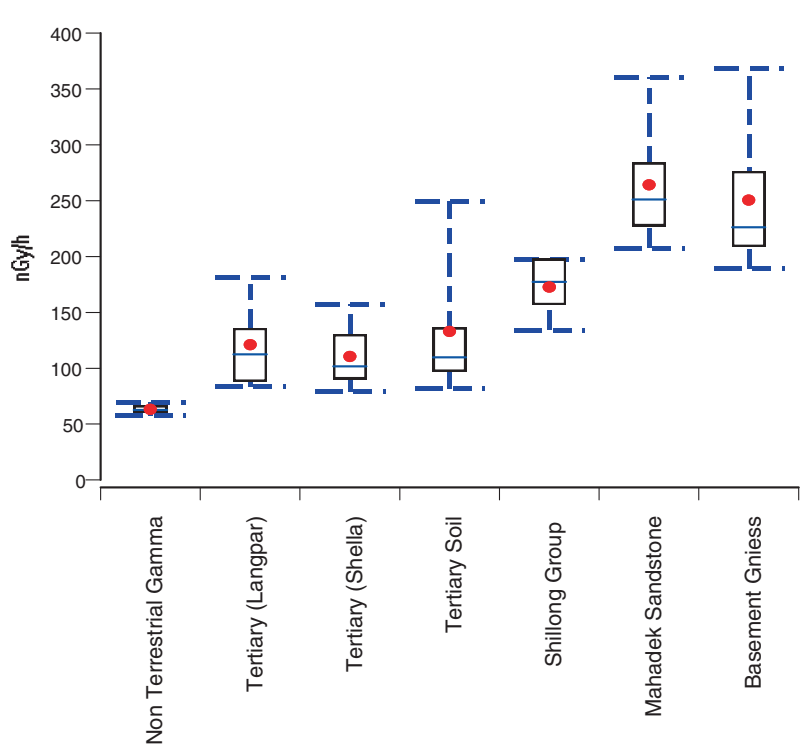

Figure 3. Typical box and whisker plot of ambient gamma levels for the major litho units of Mahadek basin. Dot represents mean ambient gamma radioactivity level.

marks and lithological occurrences to the survey route. Thus generating 320 georeference points, at an average 2.1 line $\mathrm{km}$ intervals. In-situ gamma field was measured at $1 \mathrm{~m}$ above the ground height with approximately 3 min counting time, together with lithological occurrence types. Litho unit based reproducibility of measured gamma levels was ascertained by performing random checks on few georeference points. The acquired sample data points were first clustered and represented by box plots for the major litho units of Mahadek basin. Typical prevailing gamma levels for the major litho units of Mahadek basin is plotted in figure 3 together with relative non-terrestrial gamma component (mainly cosmic, atmospheric radon and scattered gamma). This non-terrestrial gamma component was measured over the freshwater body (150 feet water column) at the Umium (MSL $965 \mathrm{~m}$ ) about $17 \mathrm{~km}$ outskirts of state capital Shillong, Meghalaya.

\subsection{Study approach}

A generalised linear estimate (Chilès and Delfiner 1999) of quantity $Z$ at unknown location $x_{0}$ (say) can be mathematically expressed as:

$$
Z_{0}^{*}=Z^{*}\left(x_{0}\right)=\sum_{i=1}^{n} \lambda_{i} Z\left(x_{i}\right)
$$

where $Z_{0}^{*}$ is the estimated value at location $x_{0}$ using data value $Z\left(x_{i}\right)$ measured at the sampling points $i$ $(=1,2,3, \ldots, n)$ each having weightage factor $\lambda_{i}$ such that:

$$
\sum_{i=1}^{n} \lambda_{i}=1
$$

Estimated value $Z_{0}^{*}$ is differentiated from the true value $Z_{0}$. Determination of weightage factor $\lambda_{i}$ is done experimentally by fitting variogram $\gamma(h)$ on the measured data values $Z\left(x_{i}\right)$ as a function of separation vector $h$ (also called lag vector) using following equation.

$$
\gamma(h)=\frac{1}{2 N_{h}} \sum_{i=1}^{N_{h}}\left[Z\left(x_{i}+h\right)-Z\left(x_{i}\right)\right]^{2}
$$

where $N_{h}$ is the number of data pairs for the specified separation vector $h$. The separation vector is denoted with certain direction and distance tolerance.

\section{Data analysis}

\subsection{Sample variogram}

Prior to the interpolation of sample data points over the study area, one need information on sample variogram using sample data points. To develop analytical model of sample variogram, variogram grid was first defined in geostatistical software $\operatorname{Surfer}^{\mathrm{TM}}$ (v 11.0) for the acquired sample data points. Subsequently, acquired sample points were then filtered for duplicate/overlapped measurements in the field by defining $\mathrm{X}$ and $\mathrm{Y}$ direction filtering criteria, each of $1.1 \mathrm{~km}$ tolerances in Surfer ${ }^{\mathrm{TM}}$ and replacing such field measurements with averaged value. A total of 114 duplicate data points were identified by the selected criteria (in analysing software) over 46 locations in the variogram grid and were replaced by equivalent average. Thus effectively giving $n=252$ active data points. Statistical summary for the two datasets (raw and filtered) is presented in table 1. Postfiltering, active data points $(n=252)$ were then processed in Surfer ${ }^{\mathrm{TM}}$ to compute sample variogram $\gamma(h)$ defined by equation (3) over all pair of observations $N_{h}$ with specified lag vector $(h)$. By default, Surfer ${ }^{\mathrm{TM}}$ defines max lag distance as one third of diagonal extent of sample data points and computes as $43.41 \mathrm{~km}$ with 25 lag points (default). This gave an average lag vector $(h) 1.74 \mathrm{~km}$, other parameters of sample variogram and grid geometry are listed in table 2 .

Thereafter, computed variogram with default lag vector $(h)$ was modelled using mathematical function that best describe the spatial relationship of sample data points. After several iterations of optimisation of sample variance (in computed variogram) including varying lag vector $1.74 \mathrm{~km}$ (default) to $1.1 \mathrm{~km}$, analytical shape of sample variogram model (figure 4) is best matched to the following theoretical model (Pannatier 1996).

$$
\gamma(h)=c_{0}+c\left[\frac{3 h}{2 a}-\frac{h^{3}}{2 a^{3}}\right]
$$

where $c_{0}, c$ and $a$ refer to nugget, partial sill and range, respectively. Table 2(b) lists detailed 
Table 1. Sample data points for variogram analysis.

\begin{tabular}{lccc}
\hline Parameters & $\begin{array}{c}\text { Unfiltered sample } \\
\text { data points }(n=320)\end{array}$ & $\begin{array}{c}\text { Filtered sample data } \\
\text { points }(n=252)\end{array}$ & Remark \\
\hline Average & 136.2 & 133.9 & $\begin{array}{c}\text { Distribution of sample data points (either case) shows domi- } \\
\text { nating contribution from gamma levels }<231 \text { nGy } / \text { h. }\end{array}$ \\
Median & 121.9 & 120.7 & $\begin{array}{c}\text { Filtering criteria for sample data points is defined as X and } \\
\text { Min }\end{array}$ \\
Max & 60 & 60.9 & Y direction tolerance 1.1 km each and replacing duplicate/ \\
Variance & 389.3 & 389.3 & overlapped data points for the said location with average \\
Std. dev. & 2633 & 2533.4 & value. \\
95 percentile & 51.3 & 50.33 & \\
\hline
\end{tabular}

Table 2. Sample variogram model ( $n=252)$.

\begin{tabular}{|c|c|c|c|c|c|}
\hline \multirow{2}{*}{\multicolumn{3}{|c|}{ (a) Variogram grid geometry }} & \multicolumn{2}{|c|}{ (b) Variogram model } & \multirow[b]{2}{*}{ Remark } \\
\hline & & & Components & Parameters & \\
\hline NN statistics & \multicolumn{2}{|l|}{ Lag parameters } & Spherical & Scale $=1020$ & Sill $=1770$ \\
\hline Min $\quad 0.033 \mathrm{~km}$ & Max lag distance & $43.41 \mathrm{~km}$ & & Range $=18.82 \mathrm{~km}$ & Nugget/Sill $=0.42$ \\
\hline $3.44 \mathrm{~km}$ & & & & Anisotropy ratio $=1.2$ & NN - Nearest \\
\hline Median $1.52 \mathrm{~km}$ & No. of lag points & 25 & & Anisotropy angle $=60^{\circ}$ & Neighbour distance. \\
\hline Average $1.59 \mathrm{~km}$ & & & & Direction $=10^{\circ}$ & To the nested sample \\
\hline \multirow{2}{*}{ Std. dev. $0.57 \mathrm{~km}$} & Lag interval (default) & $1.74 \mathrm{~km}$ & & Tolerance $=45^{\circ}$ & variogram, partial sill is \\
\hline & Lag interval (fitted) & $1.1 \mathrm{~km}$ & Nugget & 750 & referred by Surfer as scale. \\
\hline
\end{tabular}

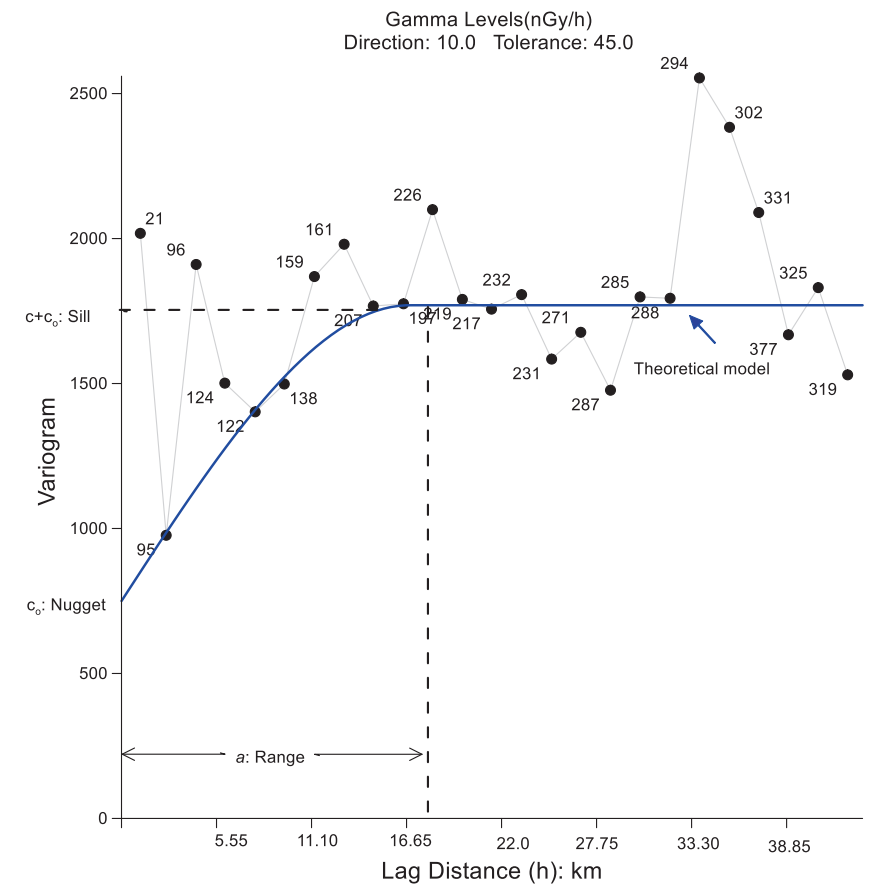

Figure 4. Analytical model of sample variogram for the Khasi Hills field measurements. Number indicates total number of observation pairs associated with each bin in the sample variogram. parameters for the analytical model of fitted sample variogram in Surfer ${ }^{\mathrm{TM}}$.

\subsection{Interpolations of experimental data points}

Prior to the interpolation of sample data points, a qualifying check on analytical model of sample variogram was performed. This was done by running compatibility check on the acquired sample data points (figure 2) using analytical model of fitted variogram model, pre-defined data filtering criteria (table 1) and interpolation grid parameters listed under table 3(a) in Surfer ${ }^{\mathrm{TM}}$. Summary of variogram analytical model based predicted results are listed in table $3(\mathrm{~b})$ and plotted on figure 5 for comparative analysis.

After ascertaining qualification of sample variogram (figure 4), defined interpolation grid presented in table 3(a) for kriging algorithm in Surfer ${ }^{\mathrm{TM}}$ was retained to interpolate active sample data points $(n=230)$ over the study area. Default grid interval $1.12 \times 1.12 \mathrm{~km}$ together with $100(\mathrm{X}$ direction) by 47 (Y direction) nodes grid geometry was used. This generated 47,000 node points for the coordinates range covered by the present field work. Interpolated gamma levels, at the grid points, were then plotted in Surfer ${ }^{\mathrm{TM}}$ to generate detailed contour maps (figure 6). 
Table 3. Compatibility check of sample variogram.

\begin{tabular}{|c|c|c|c|c|c|}
\hline \multirow{3}{*}{\multicolumn{2}{|c|}{$\frac{\text { (a) Interpolation grid geometry }}{\text { NN statistics }}$}} & \multicolumn{3}{|c|}{ (b) Statistical summary of measures } & \multirow[b]{3}{*}{ Remark } \\
\hline & & \multirow[b]{2}{*}{ Parameter } & \multirow{2}{*}{$\begin{array}{l}\text { Input sample } \\
\text { data points }\end{array}$} & \multirow{2}{*}{$\begin{array}{r}\text { Predicated } \\
\text { data points }\end{array}$} & \\
\hline & & & & & \\
\hline \multirow[t]{2}{*}{$\overline{M i n}$} & \multirow[t]{2}{*}{$0.90 \mathrm{~km}$} & Average $(n=230)$ & 134.38 & 134.13 & \multirow{4}{*}{$\begin{array}{l}\text { Sample data points are filtered using } \\
\text { pre-defined criteria in sample } \\
\text { variogram analysis (table } 1) .\end{array}$} \\
\hline & & Median & 121 & 134.82 & \\
\hline \multirow[t]{2}{*}{$\operatorname{Max}$} & \multirow[t]{2}{*}{$3.44 \mathrm{~km}$} & Min & 66.80 & 84.60 & \\
\hline & & Max & 389.30 & 288.55 & \\
\hline Median & $1.64 \mathrm{~km}$ & Variance & 2468.32 & 965.62 & \multirow{5}{*}{$\begin{array}{l}\text { Kriging minimises error (Std. dev. \& } \\
\text { RMD) while interpolating data points. }\end{array}$} \\
\hline \multirow[t]{2}{*}{ Average } & \multirow[t]{2}{*}{$1.76 \mathrm{~km}$} & Std. dev. & 49.68 & 31.07 & \\
\hline & & RMD & 0.384 & 0.264 & \\
\hline \multirow[t]{2}{*}{ Std. dev. } & \multirow[t]{2}{*}{$0.48 \mathrm{~km}$} & Skew & 1.69 & 0.40 & \\
\hline & & Kurto & 4.56 & -0.51 & \\
\hline
\end{tabular}

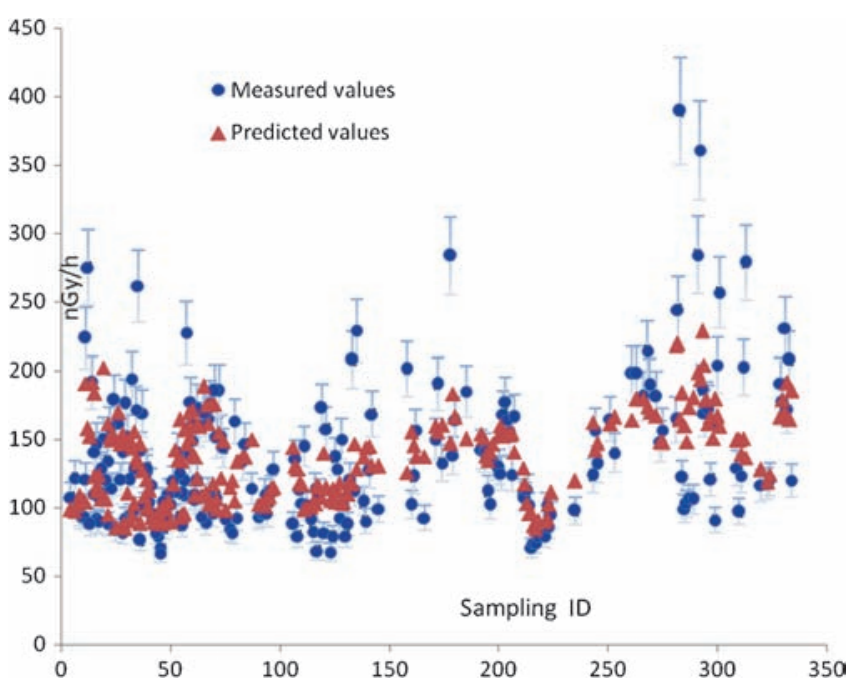

Figure 5. Comparison of variogram model predicted gamma levels to that of measured sample data points $(n=230)$ in parts of Khasi Hills, Meghalaya (India).

\section{Interpretatioin and discussion}

Mapping of ambient gamma levels in relation to the major litho units of Mahadek (figure 3) gives considerable overlap particularly to the Mahadek sandstone and basement granites. Therefore, while interpreting elevated gamma levels especially to the geological favourability areas for uranium exploration, must be considered.

Analytical model of sample variogram (figure 4) is a measure of spatial continuity of sample data points over the study area and shows reasonably good fit to that of theoretical model. High nugget and large fluctuation seen by the sample variogram (nested one) are physically observed during field measurements in the form of high nugget presence to the drawn and radiometrically analysed grab samples. Examined goodness-of-fit for the analytical model of sample variogram (figure 4) is well supported by several test measures undertaken and presented in table 3(b). Comparison of georeference data points and their predictability by the analytical model of sample variogram (figure 5) shows good match $(95 \%)$ within experimental errors, barring few high values (>231 nGy/h) sample data points (mainly basement granites in the area). This agreement between the two sets of data points, is well supported by the ANOVA test done at high degree of confidence (table 4).

Developed variogram model, used for the interpolation of sample data points over the parts of Khasi Hills gives good overview of radiometric signatures (figure 6) with elevated gamma levels towards the part of West Khasi Hills. Except for Shillong and its extension, mostly lower gamma levels are observed over the parts of East Khasi Hills. The reported lower gamma levels in parts of East Khasi Hills are much in relation to the major lithological occurrence (figure 1) in the basin and well correlated by the dominating exposure of Tertiary formation (Shella sandstone and limestone) and Sylhet Trap, both characterized with lower gamma levels (figure 3). To the Shillong and its surroundings, elevated gamma levels are mainly attributed to the Neo-Proterozoic granites and quartzites of Shillong Group of rocks having higher concentration of primordial radio elements (figure 3).

Manifested elevated gamma levels to the parts of West Khasi Hills are also lithologically well correlated on ground, since major rock exposure is attributed to the Mahadek sandstone (Upper and Lower Mahadek) and Precambrian basement granites both contributing high gamma levels (figure 3).

Presence of several high gamma anomalous zones (figure 6) identified by the study especially to the proven uranium resources in the basin, viz., Domiasiat (Kaul and Varma 1990; Sunil Kumar et al. 1990) and Wahkyn (Sen et al. 2002) confirms its application in identifying potential uranium exploration targets in the field. These identified anomalous zones are also well correlated 


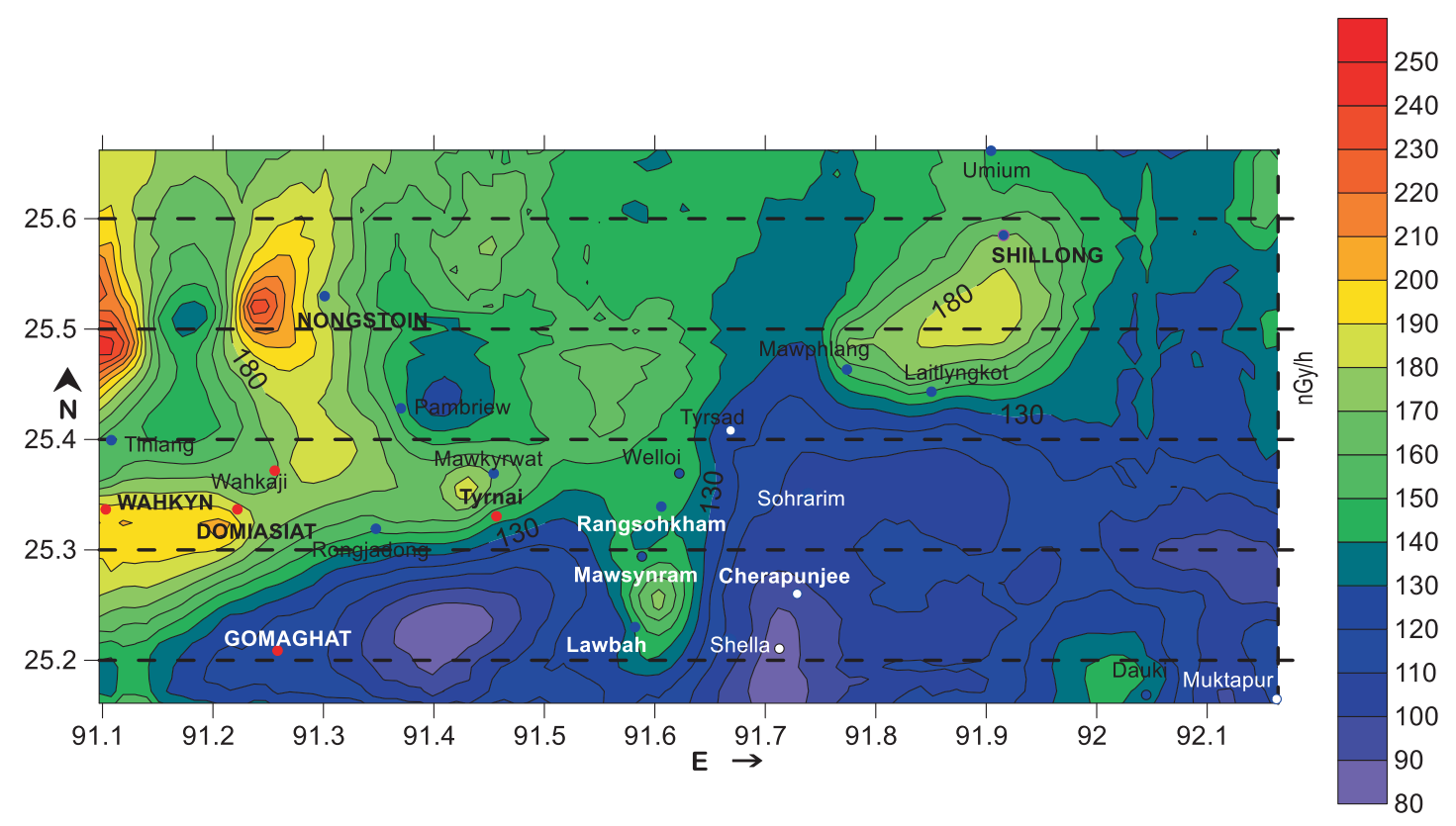

Figure 6. Interpolation of ambient gamma levels in parts of Khasi Hills, Meghalaya (India). Delineated anomalous gamma radioactivity zones (targets) are shown by yellow and red contours.

Table 4. ANOVA test for the sample variogram predicted data points.

\begin{tabular}{lcrrr}
\hline & Sum of squares & df & Mean square & F \\
\hline Between groups & 6.96 & 1 & 6.96 & 0.004 \\
Within groups & 786371.3 & 458 & 1716.97 & \\
Total & 786378.2 & 459 & & \\
\hline
\end{tabular}

to the Lower Mahadek sandstone-host rock for uranium mineralisation in the basin. Elsewhere, high gamma anomalous zone namely around Nongstoin and to the north of Tiniang (figure 6) are mainly due to basement gneiss (figure 3) and not favourable to exploration work.

\section{Conclusion}

Preliminary findings on measurements of ambient gamma levels in relation to the major litho units of Mahadek basin and its interpolation in the basin were able to delineate existing uranium occurrence. The approach demonstrated by the study work can be adopted to explore uranium bearing potential over the extended and larger part of Mahadek basin having favourable geological considerations. Modelled sample variogram shows reasonably good fit to that of theoretical model (in view of good agreement between the sample data points vis-à-vis predicted one).

Presence of high nugget seen to the developed sample variogram model still desires closure sampling interval typically to the order of lag interval $(\sim 1 \mathrm{~km})$ for detailed local characterisation and exploration of new uranium avenue especially to the extended and inaccessible areas in the basin.

\section{Acknowledgements}

The authors wish to acknowledge the support received from several of their colleagues of North East Region. They thank colleagues from Physics Lab towards instrumentation/field measurements support and field geologist for geological inputs. On the logistic part, authors are also thankful to the crew members for supporting field measurements spread over several phases in the field. Authors are highly indebted to Director, Shri P S Parihar; former Addl Director, Shri K Uma Maheshwar and Regional Director, Dr. R Mohanty of Atomic Minerals Directorate for Exploration and Research, for their kind support and constant encouragements. They are also grateful to Dr A K Rai (Addl Director, AMD) and Dr B K Bhaumik (former-in-charge Physics Lab, AMD, New Delhi) for their valuable technical inputs to this work.

\section{References}

Abraham J S and Comrie A C 2004 Real-time ozone mapping using a regression-interpolation hybrid approach, applied to Tucson, Arizona; J. Air Waste Manag. Assoc. 54(8) 914-925.

Acharya S K 1976 A summary of the Precambrian Geology of the Khasi Hills, Meghalaya; Geol. Surv. India Misc. Publ., Calcutta, 23 311p.

Baksi A K, Barman T R, Paul D K and Farrar E 1987 Widespread early cretaceous flood basalt volcanism in 
eastern India: Geochemical data from Rajmahal-BengalSylhet Traps; Chem. Geol. 63 133-141.

Chilès J Paul and Delfiner P 1999 Geostatistics: Modeling Spatial Uncertainty; John Willey \& Sons, New York.

Davis John C 2002 Statistical and Data Analysis in Geology; 3rd edn; John Willey \& Sons, New York.

Geological Survey of India (GSI) 1974 Geology and Mineral Resources of India; Geol. Surv. India Misc. Publ. Calcutta, $3077 \mathrm{p}$.

Ghosh S, Chakraborthy S, Bhalla J K, Paul D K, Sarkar A, Bishu P K and Gupta S N 1991 Geochronology and geochemistry of granite plutons from East Khasi Hills, Meghalaya; J. Geol. Soc. India 37 331-342.

Hamilton S, Mohan Rakesh, Timothy R, Bhattacharjee P, Patel A K, Majumdar A and Mohanty R 2009 Evaluation of the tectonic setting and its significance in uranium exploration in parts of Mahadek basin, Meghalaya; Proc. 96th Indian National Science Congress, Part II (abstract), Shillong, India, 50p.

Hamilton S, Bhattacharjee P, Srivastava S K, Rengarajan M, Majumdar A and Mohanthy R 2010 Geochemical approach in deciphering basinal development and uranium mineralization in parts of Mahadek basin, Meghalaya, India; Geol. Soc. India Memoir (Golden Jubilee) $\mathbf{7 5}$ 165.

Hamilton S, Bhattacharrjee P, Rakesh Mohan, Joshi G B and Mohanty R 2012 Mesozoic-Cenozoic tectonics and its implication in development of the Mahadek basin vis-àvis uranium mineralization; Geol. Soc. India Memoir $\mathbf{7 7}$ 75 .

IAEA 1990 The use of gamma ray data to define the natural radiation environment; Technical Document No. 566.

Kaul Ravi and Varma H M 1990 Geological evolution and genesis of the sandstone-type uranium deposit at Domiasiat, West Khasi Hills district, Meghalaya, India; Explor. Res. At. Miner. 3 1-16.

Kukreti B M, Pradeep Pandey and Singh R V 2012 Multivariate analysis of subsurface radiometric data in Rongsohkham area, East Khasi Hills district,
Meghalaya (India): Implication on uranium exploration; Appl. Radiat. Isot 70 1644-1648.

Kukreti B M and Pramod Kumar 2013 Developing a correlation index and $\mathrm{U}$ disequilibrium factor for the exploratory boreholes in Wahkut block of West Khasi Hills district, Meghalaya (India); Appl. Radiat. Isot. 72 6-10.

Kukreti B M, Pramod Kumar and Sharma G K 2015 Development of experimental approach to examine $\mathrm{U}$ occurrence continuity over the extended area reconnoitory boreholes: Lostoin Block, West Khasi Hills district, Meghalaya (India); Appl. Radiat. Isot. 104 $167-174$.

Matthew Kay and Roussos Dimitrakopoulos 2000 Integrated interpolation methods for geophysical data: Applications to mineral exploration; Nat. Resour. Res. 9(1) 53-63.

Nandi D R 1980 Tectonic pattern in NE India; J. Earth Sci. 7(1) 103-107.

Nucleonix Manual 2001 Environmental Radiation Monitor type ER705M, Nucleonix Systems (P) Ltd., Hyderabad (India).

Pannatier Y 1996 VarioWin-Software for spatial data analysis in 2D, Springer-Verlag, New York.

Sen D B, Sachan A S, Padhi A K and Mathur S K 2002 Uranium exploration in the Cretaceous Mahadek sediments of the Meghalava Plateau; Explor. Res. At. Miner. 14 29-58.

Srivastava S K, Kothari P K, Amit Majumdar and Umamaheswar K 2008 Occurrence of sandstone-type uranium mineralization in the Umthongkut area, Mahadek basin, West Khasi Hills district, Meghalaya, India; Curr. Sci. 94(12) 17-26.

Sunil Kumar, Rajendra Singh, Bahuguna R, Sengupta B and Ravi Kaul 1990 Geological environment of sandstonetype uranium deposit, Domiasiat area, West Khasi Hills district, Meghalaya, India; Explor. Res. At. Miner. 3 17-26.

Wright S M, Howard D C, Barry J and Smith J T 2002 Spatial variation of radio cesium deposition in Cumbria; Geogr. Environ. Modeling 6 203-216. 